\title{
HOW DOES THE G20 SUMMIT AFFECT LAND MARKET? EVIDENCE FROM CHINA
}

\author{
Xuejun DU (1) ${ }^{1}$, Zhonghua HUANG (1D) ${ }^{2, *}$ \\ ${ }^{1}$ School of Finance and Business, Shanghai Normal University, 200234 Shanghai, China \\ ${ }^{2}$ Faculty of Economics and Management, East China Normal University, 200062 Shanghai, China
}

Received 2 April 2021; accepted 13 July 2021

\begin{abstract}
We employ the difference-in-difference and synthetic control methods to investigate the capitalization effect of hosting the G20 Summit on land market, based on China's land transaction dataset from 2011 to 2019. We find that hosting the G20 Summit has a significant positive effect on land prices in the host city, increasing land prices by over $22.6 \%$ compared to comparable cities. The impact of hosting the G20 Summit on land prices is larger in the post-G20 period than in the preparation period. Further, hosting the G20 Summit has heterogeneous and distributional effects on land prices. The capitalization effects of venue construction and transportation infrastructure upgrading on land prices are the main channels.
\end{abstract}

Keywords: G20 Summit, land price, capitalization effect, mega-event, China.

\section{Introduction}

The economic impact of a mega-event has long been researched in urban studies and urban economics. A megaevent is a major, short-term event which enhances the awareness of a destination and has a measurable economic outcome (Marris, 1987; Witt, 1988). The G20 Summit, like the Olympic Games, is one of the important mega-events. Hosting the G20 Summit is an important impetus for urban development, socioeconomic progress and environmental improvement. Further, hosting the G20 Summit would advance the host city's international awareness and business potential. If bidders' or investors' perception of the host city's investment potential has increased after the G20 Summit, then this would be reflected in the land market and generate price premium in the real estate market. The positive perception and legacy of the mega-event would be capitalized in property prices (Kontokosta, 2012; Hilber, 2017).

Although hosting the G20 Summit is supposed to yield political and economic benefits, empirical study about the effect of hosting the G20 Summit on the land market is still lacked. Economic benefit capitalizing on land prices highlights the important role of land in urban development and economic growth. Land is a basic production and consumption factor for an economy. Land price movements affect the cost of production, living and the distribution of wealth (George, 1879; Huang \& Du, 2017a), which translates into broader macroeconomic impacts.

Our paper employs a quasi-natural experimental approach to investigate the impact of the G20 Summit on land prices in China. We provide new evidences on the impacts of mega-events on the land market in China. In contrast to previous studies, we further explore the heterogeneous effects and mechanisms through which a megaevent impacts on land prices.

Our paper's contribution to the literature is twofold. First, we shed new light on identifying and assessing the economic effect of the hosting G20 Summit. Previous studies focus on examining the economic impact of hosting the Olympic Games (Kontokosta, 2012; Kavetsos, 2012; Wang et al., 2015). However, hosting the G20 Summit is also an important mega-event yielding political and economic benefits, especially for China. It is no less important to estimate the economic impact of hosting the G20 Summit compared to an Olympic Games.

Second, our study contributes to the literature on how a mega-event affects land markets. Although many studies have assessed the economic, environmental and social impacts of mega-events (Tyrrell, 1987; Kuminoff \& Pope, 2012; Chen et al., 2013; Zhu et al., 2016), there have been few studies quantifying the effects of hosting a mega-event

*Corresponding author. E-mail: zhhuang@fem.ecnu.edu.cn

Copyright $\odot 2021$ The Author(s). Published by Vilnius Gediminas Technical University

This is an Open Access article distributed under the terms of the Creative Commons Attribution License (https://creativecommons.org/licenses/by/4.0/), which permits unrestricted use, distribution, and reproduction in any medium, provided the original author and source are credited. 
on the land market. In addition, a growing number of studies examine whether and how public projects or investments would be capitalized in housing prices and discuss the implications of such capitalization (Kuminoff \& Pope, 2014; Hilber, 2017). However, there are fewer studies about the effects of mega-event on land prices through public projects or investments channels.

The next section reviews the literature on the economic impact of hosting mega-events from theoretical and empirical perspectives. Section 2 is background. Section 3 is the empirical framework which describes the empirical methodology and data description. Section 4 presents the empirical results. Section 5 explores the potential impact channels. The final section concludes.

\section{Literature review}

There is a large amount of studies on the economic impact of mega-events. Previous studies about the impact of hosting an Olympic Games indicate a mixed impact, and consistent conclusions have not yet been achieved. Hosting the G20 Summit is an important strategy for a city's economic development under the context of regional competition for investment. Host city would attract investors, tourists and public awareness. Valuing the economic impact of a mega-event produced by non-academic institution has always been criticized for its subjectivity. However, rigorous studies for the effect of hosting the G20 Summit are scarce. Revealing the short-run and long-term economic impacts of hosting the G20 Summit and its legacy effects is still needed.

\subsection{Theoretical expectations}

Hosting a mega-event will spur host city's economic activities and promote the demand for real estate, and raise property prices. Hosting the G20 Summit may lead to an increase in land prices by three main channels. First, the increased infrastructure and transport facilities for hosting the G20 Summit would decrease the production costs for firms and transportation costs for consumers, which would lead to bid up land prices for better access to these positive externalities. Second, hosting G20 Summit would improve host city's urban environments and amenities, and thus would increase the demand for land and housing (Rappaport, 2009). As a result, the land market should adjust to account for the increased demand by raising prices in the short term. Third, the better public awareness and increased development potential of the host city would increase outside investors' and speculators' demand for real estate, which would also bid up land prices (Kontokosta, 2012). If these demand shocks occurred, the land prices in the host city would be bid up higher during the preparation and post-G20 Summit periods. In the preparation period, G20 Summit-related investment and increased speculation might promote land demand more than supply and result in the increase of land prices. In the
post-G20 Summit period, improved urban infrastructure and environment would increase land prices because of positive amenity effects. In addition, positive effects of the G20 Summit might bring about longer-lasting land price appreciation in the host city than in other cities.

There are other possible price impacts. First, if government officials are concerned about residents' welfare and the host city's competitiveness, they would match the cost associated with the event up to the expected benefit and land prices might remain unchanged (Kontokosta, 2012). Second, if local tax were also raised to fund the G20 Summit, as happened in 2004 Athens Olympics, the capitalization of the increased expenditure would lead to a decrease in land prices (Hilber, 2017). Third, if new land supply, fueled by expectation and speculation, outpaced demand, land prices would decrease until the existing stock were absorbed by the increasing demand (Hilber, 2017). Fourth, if G20 Summit-related investment and projects were misallocated and were not economically and socially beneficial, it would result in the decrease of land prices relative to comparable cities.

\subsection{Empirical evidences}

Most studies suggested that the economic impact of a mega-event is non-negligible (Kavetsos, 2012; Ahlfeldt \& Kavetsos, 2014). However, the impact of a mega-event on the land market has been given limited attention. Residential and commercial land prices are important indicators of a city's investment potential and economic development (Huang \& Du, 2017a), and also provide a measure of how investors perceive the mega-event.

A few studies have investigated the effect of megaevents on land markets. Most studies focused on examining the housing price effects of venue and facilities construction (Tu, 2005; Ahlfeldt \& Kavetsos, 2014). Most studies suggest that mega-event would bring positive effects on real estate prices. For example, Tu (2005) found a positive price effect for property closer to the stadium. Ahlfeldt and Kavetsos (2014) examined the effect of the two largest stadium in London on housing prices, and found that the significant positive capitalization effects were large compared with construction costs. Wang and Bao (2018) studied the impacts of hosting the Beijing Olympic Games on property prices and found that house prices increased significantly after the games. Kontokosta (2012) examined the house price effects of hosting the Olympic Games based on data from six host cities, and found that the effects depend on Olympic-related development and investment. Kavetsos (2012) estimated a positive price effect following the announcement of hosting the 2012 Olympic Games in London. Ahlfeldt and Maennig (2010) found a significant positive effect of sports arenas on land value in Berlin.

Previous studies document a variety of factors that influence the property price and the property price effect of mega-event. The property prices are generally influenced 
by individual (parcel or housing level) characteristics (Kuminoff \& Pope, 2014), neighborhood characteristics (Huang \& Du, 2015), public facilities (Hilber, 2017; Ahlfeldt \& Kavetsos, 2014), environmental attributes (Touseef et al., 2021; Du \& Huang, 2018), behavioral factors (Zhu et al., 2016), policy and institution (Huang \& Du, 2018). As to the mega-event such as Olympic Games and G20 Summit, the expected economic benefits may result in a significant shift in land prices through the capitalization of positive amenities, including urban regeneration, infrastructure construction and environment upgrading (Wang \& Bao, 2018; Kontokosta, 2012).

In addition, the literature mainly uses the hedonic price method to analyze the effect of externalities on neighboring property prices. Some literature examines the capitalization effect of positive externalities, including mega-event (Wang \& Bao, 2018; Kontokosta, 2012), environmental amenity (Du \& Huang, 2017), facilities construction (Ahlfeldt \& Maennig, 2010) and urban regeneration (Ahlfeldt et al., 2017), on property value. The other literature investigates the negative externalities, such as urban disamenity (Touseef et al., 2021), pollution (Huang \& Du, 2021) and other public bads (Currie et al., 2015), on neighboring property prices.

However, many previous studies could not identify the potential causal effect of mega-event or externality on property prices. It is because of a lack of appropriate comparable cities (only comparing between host city and host nation), failing to compare post-event outcomes and not adequately controlling for other explanatory variables.

To fill gaps, we investigate the effects of hosting the G20 on land prices based on difference-in-difference and hedonic approach. We also examine the heterogeneous and distribution effect of hosting the G20 on land prices, which provides new evidences for the effects of megaevent from China. We further apply synthetic method for obtaining robust estimates.

\section{Background}

\subsection{Hangzhou's preparation for hosting the G20 Summit}

Hangzhou was chosen to host the eleventh meeting of the Group of Twenty (the 2016 G20 Summit), which was held on 4-5 September of 2016. The probable reason why Hangzhou is choosed as the host city is that it has beautiful natural scenery, including world's famous west lake and many other famous scenic spots. In December 2015, President Xi Jinping announced that China would host the 2016 G20 Summit in Hangzhou. Hangzhou, 200 km distance to Shanghai, is the capital of Zhejiang province and located in Yangzi River Delta (Figure 1). It covers an area of $16,596 \mathrm{~km}^{2}$, with a population of 9.19 million. Hangzhou, as the other large cities, had a rapid economic growth in the past 20 years (Huang \& Du, 2015; Du \& Huang, 2017). Hangzhou's per capita GDP is 120,271 Yuan in 2016 (amount to \$18,107), ranked the 10th largest city in China.

The Chinese government attached great importance to this summit, as it is the first time that China hosted the G20 Summit. The Chinese central government appropriated US\$18 billion (almost half the cost of the Beijing 2008 Olympic Games or equal to the cost of the Guangzhou 2010 Asian Games) to Hangzhou for preparing the 2016 G20 Summit. To prepare for the G20 Summit, the Hangzhou city government carried out 605 projects including venue construction, transportation infrastructure construction and environment upgrading, most of which began after the announcement of the 2016 G20 Summit. First, the city government built the Olympic Sports Expo Town, encompassing 583.89 hectares, and located the G20 Summit venue in that town. Second, the city government upgraded the transportation infrastructure, including building ten lines of urban express road, six lines of subway, four lines of urban light railway and tunnels. Third, the city government made great efforts to renovate and upgrade the urban environment, including greening the city entrance area, renovating old neighborhoods' outer wall and regenerating the street appearance. Fourth, in terms of air quality, the government took action to close plants within a $150 \mathrm{~km}$ radius of Hangzhou central area, adding more green traffic measures and traffic control. Fifth, in term of security, Hangzhou increased the security service, including police, security check sites and devices, following the declaration that it would be hosting the G20 Summit.

These public investments and projects advanced Hangzhou's city image, transportation condition and urban environment, and thus improved the city's investment potential. Hangzhou has attracted more outside developers and investors to the real estate market since the announcement of hosting the 2016 G20 Summit. Many developers anticipated good news and expected the potential economic benefit of hosting the G20 Summit, and they bid up land prices in the land market.

\subsection{China's urban land market}

Since the opening of the urban land market in 1988, urban land can be sold as use rights were separated from ownership (Ho \& Lin, 2003; Zhu, 2005). Local governments are the de fact owners of land and they monopolize land supply in the primary land market (Tao et al., 2010; Wang et al., 2012). They sell residential and commercial land at high price for revenue and finance, while sell industrial land at low price for attracting investments and firms (Ding \& Lichtenberg, 2011).

Urban land can be sold to potential users via four transaction methods. One is negotiation, which is a nonmarket transaction method and requires one-to-one negotiation (Lin \& Ho, 2005). The other three are market transaction methods, including tender, auction and listing, 
which are more transparent and competitive (Huang \& $\mathrm{Du}, 2017 \mathrm{a}$ ). Local government generally sell residential and commercial land by market transaction methods, while they sell industrial land by negotiation (Cai et al., 2013; Huang \& Du, 2017b).

China's current land-based development model (so called the land-finance or land-revenue model) would promote the capitalization effect of holding mega-events. Land is used to finance urban construction and infrastructure investment, which also fuel up the real estate prices for capturing land revenues from land market (Huang \& $\mathrm{Du}, 2018)$. Under such background, holding Mega-events including G20 Summit and Olympic Games, would booster the land prices (Zhao et al., 2017).

\section{Empirical framework}

\subsection{Econometric specification}

For investigating the effect of hosting the G20 Summit on the land market, we employ a hedonic price model. Our identification strategy is to exploit a quasi-experimental approach. In particular, we use a difference-in-difference hedonic price model to address the omitted variables problem which often plagues traditional hedonic models. For example, the traditional hedonic models would be biased if the G20 Summit were chosen to be hosted in an area with high land prices. The difference-in-difference estimation model is specified as follows:

$$
\begin{aligned}
& \log \left(P_{i c t}\right)=\alpha+\beta_{1} \text { PostG20+ } \beta_{2} \text { Treat }+\gamma \text { Treat } \times \\
& \text { PostG20 }+\gamma X_{i c t}+u_{c}+v_{t}+\varepsilon_{i c t} .
\end{aligned}
$$

In Equation (1), the dependent variable $\log \left(P_{i c t}\right)$ is the $\log$ of the price of land parcel $i$ in city $c$ at time $t$. Our variable of interest is the interaction term of the G20 treat city dummy (Treat) and treat period (PostG20). Treat is a dummy variable equals to 1 if land parcel $i$ is in the treat group, and PostG20 is a dummy for land parcel $i$ transacted after the G20 Summit. The coefficient of
Treat $\times$ PostG20, $\gamma$, represents the average differences between host and non-host cities relative to the base time period, which is the average treatment effect of hosting the G20 Summit on land prices. $X_{i c t}$ are a set of parcellevel control variables. Our data provides land parcel characteristics including land area, land location grades (there are 18 levels of land location grade, assessed and published by city government), 7 categories of land usage, 2 types of land source and so on. We control the city fixed effect, $u_{i}$, and year-month fixed effect, $v_{t}$. In estimation, the effect of treatment dummy, Treat, is absorbed by city fixed effects.

\subsection{Data description}

We constructed a Chinese national land transaction dataset, collected from http://www.landchina.com/. It includes 345,076 land parcels for residential and commercial use, which is traded via market transaction methods in China from January 2011 to December 2019. It includes each parcel's characteristics such as selling price, area, location, land usage, transaction method, date and so on. These land parcels were sold by market transaction methods (tender, listing or auction), whose prices is determined by market. According to the preliminary statistics, 77 percent of land parcels are traded by listing method and 22 percent of parcels by auction method. More details of definition and descriptive statistics of main variables are presented in Table 1.

Our analysis consists of 197 Chinese prefecture cities. We group these cities into two categories. Hangzhou was the treatment group. We also define the other 10 cities within Zhejiang Province as an alternative treatment group, because these cities belong to the "G20 Environment Protection Cities". We also assign alternative control groups and use synthetic control method for robustness analysis. Figure 1 shows the location of our sample, which covered almost provincial capital and prefecture cities of China.

\begin{tabular}{|c|c|c|c|c|}
\hline Variables & Definition & Obs. & Mean & Std. Dev. \\
\hline Land price & Price of land parcel (yuan $/ \mathrm{m}^{2}$ ) & 345,076 & 2907.82 & 6084.32 \\
\hline \multicolumn{5}{|l|}{ Land parcel variables } \\
\hline Area & The area of land parcel (hectare) & 345,076 & 2.68 & 3.87 \\
\hline Floor area ratio & Floor area ratio for parcel & 326,432 & 4.61 & 835.39 \\
\hline Year limit & Land usage term & 264,553 & 56.03 & 14.74 \\
\hline Land location grade & Grade of land location (grade $1-18$, grade 1 has best location) & 345,076 & 5.53 & 4.59 \\
\hline \multicolumn{5}{|c|}{ Land transaction methods } \\
\hline Tender & $1=$ Land was sold through tendering & 2,419 & 0.01 & 0.08 \\
\hline Auction & $1=$ Land was sold through auction & 75,087 & 0.22 & 0.41 \\
\hline Listing & $1=$ Land was sold through listing & 267,570 & 0.77 & 0.42 \\
\hline
\end{tabular}

Table 1. Description of main variables 


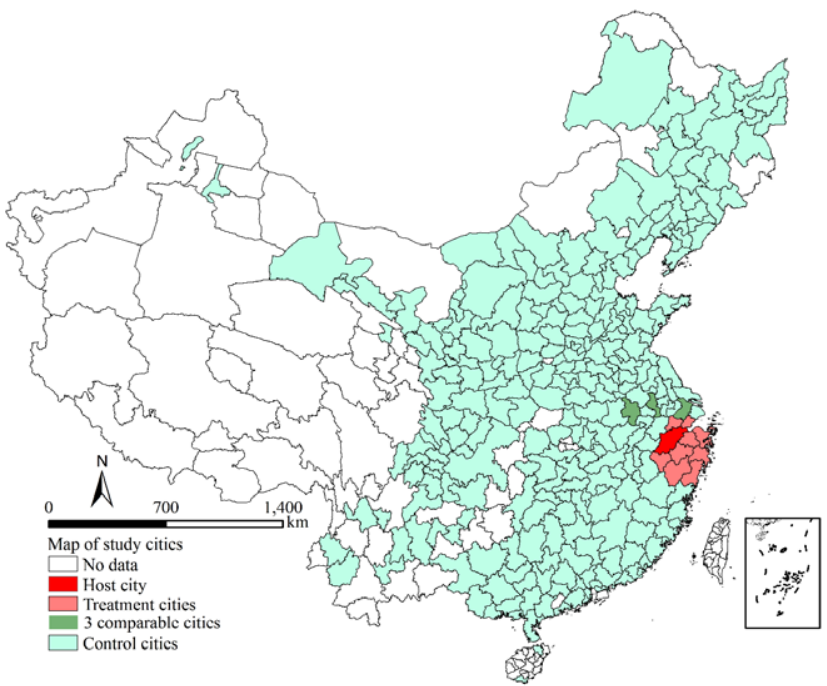

Figure 1. Map of study cities

\section{Empirical results}

\subsection{Baseline results}

Table 2 presents the baseline results. Column 1 reports the results of regressing land price (in logarithmic form) on Treat $\times$ PostG20 without including any controls. The coefficient of Treat $\times$ PostG20 is 0.392 , indicating that land prices in the host city increased by $39.2 \%$ more than in other cities after the G20 Summit. Due to fact that the land prices in the host city after the G20 Summit may be driven up by some omitted variables, we introduce some more control variables in columns $2-4$. The coefficients on the Treat $\times$ PostG20 are all statistically significant and positive. To address the multicollinearity issue, we employed VIFs (variance inflation factor) test and found no significant multicollinearity problem (VIFs of main variables is less than 5). The coefficient of Treat $\times$ PostG20 in column 4 suggests that land prices in the G20 Summit host city increase by $22.6 \%$ more than in other cities. The above results suggest that the hosting G20 Summit has a significant impact on land prices in the host city compared to other cities.

\subsection{Heterogeneous effects}

\subsubsection{Time-varying effect by G20 treatment periods}

We next examine how the effects of hosting the G20 Summit on land prices vary by period. We decompose the G20 treatment period into two spans: preparation period (PrepG20, December 2015-August 2016) and post period (PostG20, after September 2016). As shown in Table 3, host city's land prices increase significantly in G20 preparation and post periods. Compared with the preparation period, land prices increased more in the post G20 period, suggesting that positive expectation or anticipated capitalization effect of the G20 also raise the land prices in the host city.

Table 2. The effect of hosting the G20 Summit on land prices

\begin{tabular}{|c|c|c|c|c|}
\hline Variables & (1) & (2) & (3) & (4) \\
\hline \multirow[t]{2}{*}{ Treat $\times$ PostG20 } & $0.392^{* * *}$ & $0.364^{* * *}$ & $0.291^{* * *}$ & $0.226^{* * *}$ \\
\hline & $(0.019)$ & $(0.019)$ & $(0.022)$ & $(0.022)$ \\
\hline \multirow[t]{2}{*}{ PostG20 } & $0.949^{* * *}$ & $0.981^{* * *}$ & $0.955^{* * *}$ & $0.763^{* * *}$ \\
\hline & $(0.088)$ & $(0.086)$ & $(0.106)$ & $(0.105)$ \\
\hline \multirow[t]{2}{*}{ Log area } & & -0.016 & 0.004 & 0.011 \\
\hline & & $(0.012)$ & $(0.009)$ & $(0.009)$ \\
\hline \multirow[t]{2}{*}{ Land location grade } & & $-0.041^{* * *}$ & $-0.032^{* * *}$ & $-0.031^{* * *}$ \\
\hline & & $(0.003)$ & $(0.003)$ & $(0.003)$ \\
\hline \multirow[t]{2}{*}{ Year limit } & & & $0.004^{* * *}$ & 0.001 \\
\hline & & & $(0.001)$ & $(0.002)$ \\
\hline \multirow[t]{2}{*}{ Floor area ratio } & & & $0.268^{* * *}$ & $0.258^{* * *}$ \\
\hline & & & $(0.009)$ & $(0.009)$ \\
\hline \multirow[t]{2}{*}{ Constant } & $6.800^{* * *}$ & $6.999^{* * *}$ & $5.927^{* * *}$ & $6.484^{* * *}$ \\
\hline & $(0.074)$ & $(0.074)$ & $(0.112)$ & $(0.231)$ \\
\hline Land transaction methods dummies & No & No & Yes & Yes \\
\hline Other controls & No & No & No & Yes \\
\hline City fixed effects & Yes & Yes & Yes & Yes \\
\hline Year-month fixed effects & Yes & Yes & Yes & Yes \\
\hline$N$ & 345,069 & 345,069 & 244,943 & 244,943 \\
\hline$R^{2}$ & 0.416 & 0.434 & 0.532 & 0.541 \\
\hline
\end{tabular}

Notes: ${ }^{*} p<0.1,{ }^{* *} p<0.05,{ }^{* * *} p<0.01$. Standard errors are clustered at prefecture city level. Other controls consist of land quality grade, land use and land source variables. We do not report the coefficient for Treat, as the effect of treatment dummy, Treat, is absorb by city fixed effects. 
Table 3. Time varying effects of hosting the G20 Summit on land prices

\begin{tabular}{|c|c|c|c|}
\hline Variables & (1) & (2) & (3) \\
\hline \multirow[t]{2}{*}{ Treat $\times$ PrepG20 } & $0.087^{* *}$ & & $0.194^{* \star *}$ \\
\hline & $(0.018)$ & & $(0.020)$ \\
\hline \multirow[t]{2}{*}{ Treat $\times$ PostG20 } & & $0.225^{* * *}$ & $0.256^{* * *}$ \\
\hline & & $(0.022)$ & $(0.021)$ \\
\hline \multirow[t]{2}{*}{ PrepG20 } & $0.539^{\star * \star}$ & & $0.188^{* \star *}$ \\
\hline & $(0.105)$ & & $(0.019)$ \\
\hline \multirow[t]{2}{*}{ PostG20 } & & $0.763^{* * *}$ & $0.421^{* * *}$ \\
\hline & & $(0.105)$ & $(0.020)$ \\
\hline \multirow[t]{2}{*}{ Log area } & 0.011 & 0.011 & 0.012 \\
\hline & $(0.009)$ & $(0.009)$ & $(0.009)$ \\
\hline \multirow[t]{2}{*}{ Land location grade } & $-0.031^{* * *}$ & $-0.031^{* * *}$ & $-0.030^{* * *}$ \\
\hline & $(0.003)$ & $(0.003)$ & $(0.003)$ \\
\hline \multirow[t]{2}{*}{ Year limit } & 0.001 & 0.001 & 0.001 \\
\hline & $(0.002)$ & $(0.002)$ & $(0.002)$ \\
\hline \multirow[t]{2}{*}{ Floor area ratio } & $0.258^{* * *}$ & $0.258^{* * \star}$ & $0.259^{* \star *}$ \\
\hline & $(0.009)$ & $(0.009)$ & $(0.009)$ \\
\hline \multirow[t]{2}{*}{ Constant } & $6.487^{* * *}$ & $6.486^{* * *}$ & $6.756^{* * *}$ \\
\hline & $(0.232)$ & $(0.232)$ & $(0.206)$ \\
\hline Land transaction methods dummies & No & Yes & Yes \\
\hline Other controls & No & No & Yes \\
\hline City fixed effects & Yes & Yes & Yes \\
\hline Year-month fixed effects & Yes & Yes & Yes \\
\hline Observations & 244943 & 244943 & 244943 \\
\hline$R^{2}$ & 0.540 & 0.540 & 0.533 \\
\hline
\end{tabular}

Notes: ${ }^{*} p<0.1,{ }^{* *} p<0.05,{ }^{* * *} p<0.01$. Standard errors clustered at prefecture city level are reported in parentheses. Other controls are land usage and land source dummy variables.

\subsubsection{Spatial heterogeneous effect of G20 on land prices}

For exploring the spatial heterogeneous effect of the G20 on land prices, we define two group of cities (strictly environmental regulation areas and environmental regulation areas) within Zhejiang Province as "G20 Environmental Protection Cities" according to the G20 Summit Environmental Protection Program published by the Zhejiang Province government. These cities also implemented strict measures of environment protection for supporting the host of G20 Summit in Hangzhou. The first group of cities, referred to as strictly environmental regulation areas (within $150 \mathrm{~km}$ distance to Hangzhou), include Ningbo, Huzhou, Jiaxing, Shaoxing, Jinhua and Quzhou (Treat ${ }_{1}$ ). The second group of cities are environmental regulation areas $(150-300 \mathrm{~km}$ distance to Hangzhou), including Wenzhou, Zhoushan, Taizhou and Lishui $\left(\right.$ Treat $\left._{2}\right)$. We run the following regression:

$$
\begin{aligned}
& \log \left(P_{\text {ict }}\right)=\alpha+\beta \text { Treat } \times \text { PostG20 }+\beta_{1} \text { Treat }_{1} \times \\
& \text { PostG20 }+\beta_{2} \text { Treat }_{2} \times \text { PostG } 20+\gamma X_{i c t}+u_{i}+v_{t}+\varepsilon_{\text {ict }},
\end{aligned}
$$

where the coefficients on Treat $\times$ PostG20, Treat $1 \times$ PostG20 and Treat ${ }_{2} \times$ PostG20 represent the effect of hosting G20 Summit on land prices in the different groups of potential treated cities.
Table 4 presents the heterogeneous effect of the G20 on land prices. In columns 1-4, the coefficients of Treat $\times$ PostG20 are all significantly positive. The coefficients of Treat $1 \times$ PostG20 are only minor significant in column 1. However, the coefficients of Treat ${ }_{2} \times$ PostG20 are not significant. These results suggest that hosting the G20 Summit does not have significant spatial heterogeneous effects on land prices in other supporting cities.

\subsubsection{Heterogeneous effect of G20 on land prices across residential and commercial land}

We next separate the residential and commercial land samples and test the heterogeneous effects of hosting the G20 Summit. Table 5 provides the estimation results. The coefficients of Treat $\times$ PostG 20 are both significant and positive in columns 1-2, indicating that hosting the G20 Summit has significantly positively effects for residential and commercial land. The effect is larger for residential land than that for commercial land. This is because that the benefit of urban infrastructure construction and environment upgrading for hosting the G20 Summit is easier to be capitalized into the residential land price than into commercial land price, especially in city with restricted residential land supply. 
Table 4. Heterogeneous effect of hosting the G20 Summit on land prices

\begin{tabular}{|c|c|c|c|c|}
\hline Variables & (1) & (2) & (3) & (4) \\
\hline \multirow[t]{2}{*}{ Treat $\times$ PostG20 } & $0.397^{* * *}$ & $0.368^{* * *}$ & $0.296^{* *}$ & $0.228^{* * *}$ \\
\hline & $(0.019)$ & $(0.020)$ & $(0.022)$ & $(0.023)$ \\
\hline \multirow[t]{2}{*}{ Treat $_{1} \times$ PostG20 } & $0.096^{*}$ & 0.080 & 0.089 & 0.052 \\
\hline & $(0.057)$ & $(0.054)$ & $(0.083)$ & $(0.081)$ \\
\hline \multirow[t]{2}{*}{ Treat $_{2} \times$ PostG20 } & 0.043 & 0.056 & 0.036 & -0.032 \\
\hline & $(0.036)$ & $(0.041)$ & $(0.153)$ & $(0.146)$ \\
\hline \multirow[t]{2}{*}{ PostG20 } & $0.942^{* * *}$ & $0.975^{\text {***}}$ & $0.948^{* * *}$ & $0.761^{\star * *}$ \\
\hline & $(0.088)$ & $(0.086)$ & $(0.105)$ & $(0.104)$ \\
\hline \multirow[t]{2}{*}{ Log area } & & -0.016 & 0.005 & 0.011 \\
\hline & & $(0.012)$ & $(0.009)$ & $(0.009)$ \\
\hline \multirow[t]{2}{*}{ Land location grade } & & $-0.041^{* * *}$ & $-0.032^{* * *}$ & $-0.031^{* * *}$ \\
\hline & & $(0.003)$ & $(0.003)$ & $(0.003)$ \\
\hline \multirow[t]{2}{*}{ Year limit } & & & $0.004^{* * *}$ & 0.001 \\
\hline & & & $(0.001)$ & $(0.002)$ \\
\hline \multirow[t]{2}{*}{ Floor area ratio } & & & $0.268^{* * *}$ & $0.258^{* * *}$ \\
\hline & & & $(0.009)$ & $(0.009)$ \\
\hline \multirow[t]{2}{*}{ Constant } & $6.803^{* * *}$ & $7.002^{* * *}$ & $5.934^{* * *}$ & $6.489^{* * *}$ \\
\hline & $(0.073)$ & $(0.074)$ & $(0.113)$ & $(0.232)$ \\
\hline Land transaction methods dummies & No & No & Yes & Yes \\
\hline Other controls & No & No & No & Yes \\
\hline City fixed effects & Yes & Yes & Yes & Yes \\
\hline Year-month fixed effects & Yes & Yes & Yes & Yes \\
\hline Observations & 345069 & 345069 & 244943 & 244943 \\
\hline$R^{2}$ & 0.415 & 0.433 & 0.531 & 0.540 \\
\hline
\end{tabular}

Notes: ${ }^{*} p<0.1,{ }^{* *} p<0.05,{ }^{* * *} p<0.01$. Standard errors clustered at prefecture city level are reported in parentheses. Other controls consist of land usage and land source dummy variables. Treat ${ }_{1}$, within $150 \mathrm{~km}$ distance to Hangzhou, includes Ningbo, Huzhou, Jiaxing, Shaoxing, Jinhua and Quzhou. Treat ${ }_{2}, 150-300 \mathrm{~km}$ distance to Hangzhou, includes Wenzhou, Zhoushan, Taizhou and Lishui.

Table 5. Heterogeneous effect of hosting the G20 Summit across residential and commercial land

\begin{tabular}{|l|c|c|}
\hline \multirow{2}{*}{ Variables } & Residential land & Commercial land \\
\cline { 2 - 3 } & $(1)$ & $(2)$ \\
\hline Treat $\times$ PostG20 & $0.481^{* * *}$ & $(0.026)$ \\
\hline PostG20 & $(0.027)$ & $0.482^{* * *}$ \\
\cline { 2 - 3 } & $1.108^{* * *}$ & $(0.089)$ \\
\hline Log area & $(0.145)$ & -0.002 \\
\hline Land location grade & $0.031^{* * *}$ & $(0.010)$ \\
\cline { 2 - 3 } & $(0.011)$ & $-0.036^{* * *}$ \\
\hline Year limit & $-0.028^{* * *}$ & $(0.003)$ \\
\hline Floor area ratio & $(0.004)$ & 0.002 \\
\hline Constant & -0.004 & $(0.003)$ \\
\hline Land transaction methods dummies & $(0.004)$ & $0.286^{* * *}$ \\
\hline Other controls & $0.280^{* * *}$ & $(0.012)$ \\
\hline City fixed effects & $(0.010)$ & $6.477^{* * *}$ \\
\hline Year-month fixed effects & $6.467^{* *}$ & $(0.141)$ \\
\hline$N$ & $(0.304)$ & Yes \\
\hline$R^{2}$ & Yes & Yes \\
\cline { 2 - 3 } & Yes & Yes \\
\hline
\end{tabular}

Notes: ${ }^{*} p<0.1,{ }^{* *} p<0.05,{ }^{* * *} p<0.01$. Standard errors are clustered at prefecture city level. Other controls consist of land quality grade, land use and land source variables. We do not report the coefficient for Treat, as the effect of treatment dummy, Treat, is absorb by city fixed effects. 


\subsection{Robust analysis}

\subsubsection{Addressing other policies' effects}

We further test the potential effects of other policies for excluding the possibilities that the increase in land prices may be induced by other policies. In 2011 and 2019, Hangzhou city government put forward two important housing control policies, which may affect land prices. The first policy is Restricting Land Prices and Competing Constructing Public Housing, which published on October 18th, 2012. This policy requires that developer must bid for constructing more public housing when the land bidding price exceeds $149 \%$ of the reserve prices. The second policy is Withdrawing Housing Purchasing Restricting, carrying out on August 29th, 2014. We create two dummies for this two policies (Restricting Land Prices, Competing Constructing Public Housing; Withdrawing Housing Purchasing Restricting) and then interact with the treat variable. Table 6 presents the estimation results. The coefficients of Treat $\times$ PostG20 keep significantly positive after controlling the above two policies and across columns $1-4$. This result confirms that the effects of hosting G20 Summit on land prices is not induced by other policies.

\subsubsection{Parallel trend test}

We further test the parallel trend assumption underlying our difference-in-difference approach. We estimate Equation (1) to investigate the dynamic effect of the residential land prices responding to G20 Summit, using the same control variables. Figure 2 presents the parallel trend test results for the coefficients of interaction (treat ${ }^{*}$ yearquarter), which shows the estimated land price difference between the treated and control groups. The average land price difference is almost statistically insignificant before the announcement of G20 Summit and in 2013-2015, but began to increase and became positive and statistically significant during the construction period, which supports the parallel trend assumption of the same trend before the event. As Hangzhou city government published housing purchasing policy in September 19, 2016 (15 days after the opening of G20 Summit), land prices decreased and the average land price difference between the treated and control groups becomes insignificant for 2 quarters. However, it began to increase and positive for the most quarters of 2018-2019, which also overall supports the parallel trend assumption.

Table 6. Addressing other policies' effect on land prices

\begin{tabular}{|c|c|c|c|c|}
\hline Variables & (1) & (2) & (3) & (4) \\
\hline \multirow[t]{2}{*}{ Treat $\times$ PostG20 } & $0.377^{* * *}$ & $0.389^{* * *}$ & $0.315^{* * *}$ & $0.251^{* * *}$ \\
\hline & $(0.016)$ & $(0.016)$ & $(0.018)$ & $(0.019)$ \\
\hline \multirow{2}{*}{$\begin{array}{l}\text { Treat } \times \text { Restricting land prices, competing } \\
\text { constructing public housing }\end{array}$} & $0.182^{* * *}$ & $0.158^{* * *}$ & $0.079^{* * *}$ & $0.105^{* * *}$ \\
\hline & $(0.019)$ & $(0.019)$ & $(0.022)$ & $(0.023)$ \\
\hline \multirow[t]{2}{*}{ Treat $\times$ Withdrawing housing purchasing restricting } & $-0.065^{* * *}$ & $-0.109^{* * *}$ & $-0.067^{* * *}$ & $-0.082^{* * *}$ \\
\hline & $(0.016)$ & $(0.016)$ & $(0.016)$ & $(0.016)$ \\
\hline \multirow[t]{2}{*}{ PostG20 } & $0.538^{* * *}$ & $0.550^{* * *}$ & $0.440^{* * *}$ & $0.224^{* * *}$ \\
\hline & $(0.057)$ & $(0.055)$ & $(0.060)$ & $(0.062)$ \\
\hline \multirow{2}{*}{$\begin{array}{l}\text { Restricting land prices, competing } \\
\text { constructing public housing }\end{array}$} & $0.220^{* *}$ & $0.255^{* * *}$ & $0.382^{* * *}$ & $0.404^{* * *}$ \\
\hline & $(0.095)$ & $(0.093)$ & $(0.104)$ & $(0.105)$ \\
\hline \multirow[t]{2}{*}{ Withdrawing housing purchasing restricting } & $0.187^{* * *}$ & $0.174^{* * *}$ & $0.132^{* *}$ & $0.135^{* *}$ \\
\hline & $(0.069)$ & $(0.066)$ & $(0.054)$ & $(0.059)$ \\
\hline \multirow[t]{2}{*}{ Log area } & & -0.016 & 0.005 & 0.011 \\
\hline & & $(0.012)$ & $(0.009)$ & $(0.009)$ \\
\hline \multirow[t]{2}{*}{ Land location grade } & & $-0.041^{* * *}$ & $-0.032^{* * *}$ & $-0.031^{* * *}$ \\
\hline & & $(0.003)$ & $(0.003)$ & $(0.003)$ \\
\hline \multirow[t]{2}{*}{ Year limit } & & & $0.004^{* * *}$ & 0.001 \\
\hline & & & $(0.001)$ & $(0.002)$ \\
\hline \multirow[t]{2}{*}{ Floor area ratio } & & & $0.268^{* * *}$ & $0.258^{* * *}$ \\
\hline & & & $(0.009)$ & $(0.009)$ \\
\hline \multirow[t]{2}{*}{ Constant } & $6.803^{* * *}$ & $7.002^{* * *}$ & $5.932^{* * *}$ & $6.487^{* * *}$ \\
\hline & $(0.074)$ & $(0.075)$ & $(0.113)$ & $(0.232)$ \\
\hline Land transaction methods dummies & No & No & Yes & Yes \\
\hline Other controls & No & No & No & Yes \\
\hline City fixed effects & Yes & Yes & Yes & Yes \\
\hline Year-month fixed effects & Yes & Yes & Yes & Yes \\
\hline$N$ & 345069 & 345069 & 244943 & 244943 \\
\hline$R^{2}$ & 0.415 & 0.433 & 0.531 & 0.540 \\
\hline
\end{tabular}

Notes: ${ }^{*} p<0.1,{ }^{* *} p<0.05,{ }^{* * *} p<0.01$. Standard errors are clustered at prefecture city level. Other controls consist of land quality grade, land use and land source variables. 


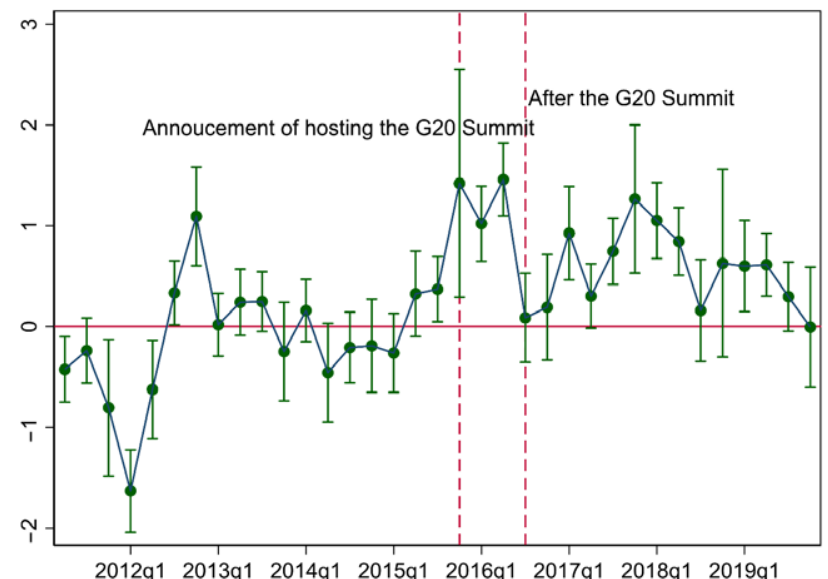

Figure 2. Parallel trend test (95\% confidence intervals)

\subsubsection{Results of synthetic control method}

We next use synthetic control method for addressing the concern of using the non-G20 host cities as the control group. We use log GDP, log population, third industrial output ratio, log investment, log foreign direct investment as predictor variables for constructing synthetic control group and calculating the weights. Table 7 presents log land prices predictor means for treated and synthetic group, comparing the pretreatment characteristics between actual Hangzhou and synthetic Hangzhou. As seen, the land prices predictor means between treated and synthetic group is close, and seems to provide a suitable control group for Hangzhou.

Table 7. Log land price predictor means

\begin{tabular}{|l|c|c|}
\hline \multicolumn{1}{|c|}{ Variables } & Treated group & Synthetic group \\
\hline Log per capita GDP & 18.283 & 18.445 \\
\hline Log population & 6.568 & 6.632 \\
\hline $\begin{array}{l}\text { Share of third industrial } \\
\text { output }\end{array}$ & 54.136 & 54.472 \\
\hline Log per capita FDI & 17.613 & 17.772 \\
\hline $\begin{array}{l}\text { Log per capita fixed } \\
\text { investments }\end{array}$ & 15.058 & 15.179 \\
\hline
\end{tabular}

Figure 3 shows displays the log land prices for Hangzhou (treated group) and its synthetic counterpart (weighted average of other Chinese cities). There is parallel trend for the land prices among treated and synthetic control groups before the hosting G20 Summit. The log land prices of treated group respond with a lag and then significantly rise after the G20 Summit compared to synthetic control group. However, the log land prices of synthetic control group decrease in 2017, and the price difference between treated and synthetic control groups become much larger after the G20 Summit. The result of synthetic control method again confirms the above results and the assumption of parallel trend.

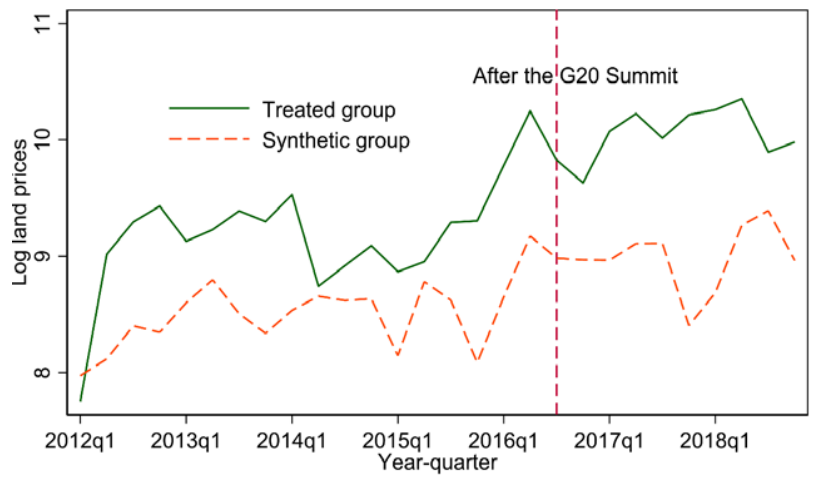

Figure 3. Result of synthetic control method

\section{Impact channels of hosting the G20 Summit on the land market}

We further investigate the channels through which hosting the G20 Summit affects host city' land prices. Although the above analysis suggests that land prices increased in Hangzhou during and after the 2016 G20 Summit, it is important to explore which actions or investments were effective in increasing Hangzhou's land prices, to guide future policy intervention. Four major kinds of investments were implemented during the preparation period: venue construction, transportation infrastructure construction, urban environment upgrading and air quality protection. Distinguishing between these actions is difficult, for they overlap in time and their effects take time to emerge and dissipate. This section focusses on the location and timing of venue and transportation infrastructure construction in Hangzhou.

Figure 4 shows the spatial locations of the G20-related venue, transportation infrastructure projects and selected land parcels. As shown, the selected land parcels are spatially distributed over all eight districts of Hangzhou and have much variance in distance to the G20-related venue or transportation infrastructure projects.

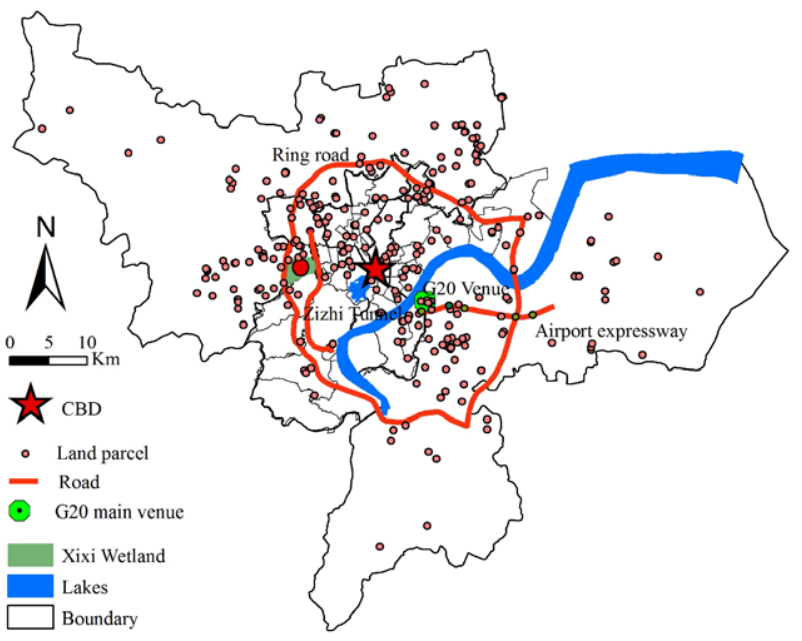

Figure 4. G20 venue, transportation infrastructure projects and land parcels 
To examine the effects of G20-related investment projects on land prices, we use a set of dummy variables for different levels of distance to the G20 main venue or transportation infrastructure junction, including $<10 \mathrm{~km}$, $10-20 \mathrm{~km}$ and $20-40 \mathrm{~km}$. Compared to the previous literature of the externalities effects on nearby housing price, our sample divisions for distance are larger as our land transaction data sample are more spatially dispersed. We also control land parcel characteristic, locational (land location grade, distance to CBD, distance to closest subway and bus station), and environmental attributes (distance to West Lake, Xixi Wetland, and Qiantang River).

\subsection{Impact of $\mathrm{G} 20$ venue construction on land prices}

Table 8 reports the results for the impact of G20 main venue construction on land prices. In column 1, the coefficient on $10 \mathrm{~km}$ distance to Venue $\times$ PostG20 is statistically insignificant. The results in columns $2-3$ show that the coefficients of $10-20 \mathrm{~km}$ distance to VenuexPostG20 and $20-40 \mathrm{~km}$ distance to Venue $\times$ PostG20 are both significantly positive. Column 4 shows that the land near the G20 venue has a significant price premium after the G20 Summit. Comparing the coefficients in column 4 , the proximity value of the G20 venue is largest with $10-20 \mathrm{~km}$ distance to the venue,

Table 8. Effect of G20 main venue construction on land prices

\begin{tabular}{|c|c|c|c|c|}
\hline Variables & (1) & (2) & (3) & (4) \\
\hline \multirow{2}{*}{$\begin{array}{l}<10 \mathrm{~km} \text { distance to Venue } \\
\times \text { PostG20 }\end{array}$} & -0.062 & & & $0.515^{* * *}$ \\
\hline & $(0.125)$ & & & $(0.143)$ \\
\hline \multirow{2}{*}{$\begin{array}{l}10-20 \mathrm{~km} \text { distance to Venue } \\
\times \text { PostG20 }\end{array}$} & & $0.509^{* *}$ & & $0.857^{* * *}$ \\
\hline & & $(0.184)$ & & $(0.216)$ \\
\hline \multirow{2}{*}{$\begin{array}{l}\text { 20-40 km distance to Venue } \\
\times \text { PostG20 }\end{array}$} & & & $0.398^{* *}$ & $0.674^{* * *}$ \\
\hline & & & $(0.120)$ & $(0.110)$ \\
\hline \multirow[t]{2}{*}{$<10 \mathrm{~km}$ distance to Venue } & -0.176 & & & -0.034 \\
\hline & $(0.106)$ & & & $(0.324)$ \\
\hline \multirow[t]{2}{*}{$10-20 \mathrm{~km}$ distance to Venue } & & -0.049 & & 0.032 \\
\hline & & $(0.083)$ & & $(0.213)$ \\
\hline \multirow[t]{2}{*}{ 20-40 km distance to Venue } & & & 0.002 & 0.099 \\
\hline & & & $(0.155)$ & $(0.088)$ \\
\hline \multirow[t]{2}{*}{ Log area } & -0.040 & -0.043 & -0.037 & -0.051 \\
\hline & $(0.051)$ & $(0.050)$ & $(0.053)$ & $(0.053)$ \\
\hline \multirow[t]{2}{*}{ Land location grade } & $-0.124^{* * *}$ & $-0.117^{* * *}$ & $-0.119^{* * *}$ & $-0.123^{* * *}$ \\
\hline & $(0.024)$ & $(0.023)$ & $(0.029)$ & $(0.027)$ \\
\hline \multirow[t]{2}{*}{ Year limit } & 0.010 & 0.012 & 0.012 & 0.014 \\
\hline & $(0.009)$ & $(0.009)$ & $(0.010)$ & $(0.009)$ \\
\hline \multirow[t]{2}{*}{ Floor area ratio } & $0.203^{* *}$ & $0.199^{* *}$ & $0.199^{* *}$ & $0.205^{* *}$ \\
\hline & $(0.070)$ & $(0.074)$ & $(0.072)$ & $(0.069)$ \\
\hline \multirow[t]{2}{*}{ Log distance to CBD } & $-0.401^{* *}$ & $-0.366^{*}$ & $-0.360^{*}$ & $-0.403^{*}$ \\
\hline & $(0.164)$ & $(0.167)$ & $(0.174)$ & $(0.188)$ \\
\hline \multirow[t]{2}{*}{ Log distance to closest subway station } & 0.079 & 0.060 & $0.066^{*}$ & $0.070^{*}$ \\
\hline & $(0.045)$ & $(0.039)$ & $(0.034)$ & $(0.035)$ \\
\hline \multirow[t]{2}{*}{ Log distance to closest bus station } & $-0.158^{* *}$ & $-0.151^{* *}$ & $-0.150^{* *}$ & $-0.163^{* *}$ \\
\hline & $(0.063)$ & $(0.059)$ & $(0.064)$ & $(0.058)$ \\
\hline \multirow[t]{2}{*}{ Log distance to West Lake } & -0.201 & -0.193 & -0.212 & -0.209 \\
\hline & $(0.189)$ & $(0.183)$ & $(0.164)$ & $(0.169)$ \\
\hline \multirow[t]{2}{*}{ Log distance to Xixi Wetland } & -0.101 & -0.127 & -0.143 & -0.101 \\
\hline & $(0.133)$ & $(0.118)$ & $(0.129)$ & $(0.128)$ \\
\hline \multirow[t]{2}{*}{ Log distance to Qiantang River } & -0.029 & -0.001 & -0.005 & -0.012 \\
\hline & $(0.075)$ & $(0.076)$ & $(0.080)$ & $(0.084)$ \\
\hline \multirow[t]{2}{*}{ Constant } & $16.913^{* * *}$ & $16.357^{* * *}$ & $16.664^{* * *}$ & $16.612^{* * *}$ \\
\hline & $(1.200)$ & $(1.084)$ & $(0.969)$ & $(1.238)$ \\
\hline Land transaction methods dummies & Yes & Yes & Yes & Yes \\
\hline Other controls & Yes & Yes & Yes & Yes \\
\hline Year fixed effects & Yes & Yes & Yes & Yes \\
\hline District fixed effects & Yes & Yes & Yes & Yes \\
\hline Observations & 390 & 390 & 390 & 390 \\
\hline$R^{2}$ & 0.711 & 0.716 & 0.712 & 0.727 \\
\hline
\end{tabular}

Notes: ${ }^{*} p<0.1,{ }^{* *} p<0.05,{ }^{* * *} p<0.01$. Standard errors clustered at prefecture city level are reported in parentheses. Other controls consist of land usage and land source dummy variables. Land location grade represents location quality. 
second in 20-40 km distance to the venue and least within $10 \mathrm{~km}$ distance to the venue. Compared to existing evidence that sports facilities influence property values within a range of 3-5 km (Ahlfeldt \& Maennig, 2010; Ahlfeldt \& Kavetsos, 2014), the impact of the G20 main venue on land prices is much larger and within a wide range of $0-40 \mathrm{~km}$.

\subsection{Impact of transportation infrastructure upgrading on land prices}

To prepare for the G20 Summit, Hangzhou city implemented two main transportation infrastructure upgrading projects. One was the G20-related expressway, named the airport expressway, connecting the G20 venue and the airport. The other was the Zizhi Tunnel, the city's fourth arterial highway, which improved the connectedness of the west and east areas of Hangzhou to the east of city. These two key projects improved Hangzhou's transportation infrastructure and investment environment. They are hypothesized to increase land prices in the areas of benefit.

Table 9 presents the results of the effect of G20-related expressway construction on land prices. In column 4 , land parcels near the G20-related expressway increased after the G20 Summit. In comparison, land prices increased more at a $10-40 \mathrm{~km}$ distance from the expressway than

Table 9. Effect of G20 related express way construction on land prices

\begin{tabular}{|c|c|c|c|c|}
\hline Variables & $(1)$ & $(2)$ & (3) & $(4)$ \\
\hline \multirow{2}{*}{$\begin{array}{l}<10 \mathrm{~km} \text { distance to G20 Expressway } \\
\times \text { PostG20 }\end{array}$} & -0.003 & & & $0.527^{* * *}$ \\
\hline & $(0.183)$ & & & $(0.157)$ \\
\hline \multirow{2}{*}{$\begin{array}{l}\text { 10-20 km distance to G20 Expressway } \\
\times \text { PostG20 }\end{array}$} & & 0.388 & & $0.911^{* *}$ \\
\hline & & $(0.315)$ & & $(0.367)$ \\
\hline \multirow{2}{*}{$\begin{array}{l}20-40 \mathrm{~km} \text { distance to G20 Expressway } \\
\times \text { PostG20 }\end{array}$} & & & $0.496^{* * *}$ & $0.805^{* * *}$ \\
\hline & & & $(0.129)$ & $(0.123)$ \\
\hline \multirow[t]{2}{*}{$<10 \mathrm{~km}$ distance to G20 Expressway } & -0.011 & & & 0.081 \\
\hline & $(0.144)$ & & & $(0.203)$ \\
\hline \multirow[t]{2}{*}{ 10-20 km distance to G20 Expressway } & & -0.092 & & 0.002 \\
\hline & & $(0.110)$ & & $(0.120)$ \\
\hline \multirow[t]{2}{*}{ 20-40 km distance to G20 Expressway } & & & -0.008 & 0.053 \\
\hline & & & $(0.161)$ & $(0.066)$ \\
\hline \multirow[t]{2}{*}{ Log area } & -0.036 & -0.035 & -0.045 & -0.047 \\
\hline & $(0.051)$ & $(0.049)$ & $(0.050)$ & $(0.049)$ \\
\hline \multirow[t]{2}{*}{ Land location grade } & $-0.117^{* * *}$ & $-0.116^{* * *}$ & $-0.122^{* * *}$ & $-0.117^{* * *}$ \\
\hline & $(0.028)$ & $(0.025)$ & $(0.032)$ & $(0.031)$ \\
\hline \multirow[t]{2}{*}{ Year limit } & 0.011 & 0.012 & 0.012 & 0.014 \\
\hline & $(0.008)$ & $(0.008)$ & $(0.009)$ & $(0.008)$ \\
\hline \multirow[t]{2}{*}{ Floor area ratio } & $0.200^{* *}$ & $0.195^{* *}$ & $0.205^{* *}$ & $0.202^{* *}$ \\
\hline & $(0.068)$ & $(0.072)$ & $(0.070)$ & $(0.065)$ \\
\hline \multirow[t]{2}{*}{ Log distance to CBD } & $-0.354^{*}$ & $-0.354^{*}$ & $-0.377^{*}$ & $-0.352^{*}$ \\
\hline & $(0.166)$ & $(0.167)$ & $(0.167)$ & $(0.176)$ \\
\hline \multirow[t]{2}{*}{ Log distance to closest subway station } & 0.067 & 0.061 & 0.063 & 0.061 \\
\hline & $(0.047)$ & $(0.041)$ & $(0.037)$ & $(0.039)$ \\
\hline \multirow[t]{2}{*}{ Log distance to closest bus station } & $-0.147^{*}$ & $-0.154^{* *}$ & $-0.139^{*}$ & $-0.157^{* *}$ \\
\hline & $(0.069)$ & $(0.064)$ & $(0.061)$ & $(0.065)$ \\
\hline \multirow[t]{2}{*}{ Log distance to West Lake } & -0.208 & -0.211 & -0.214 & -0.230 \\
\hline & $(0.177)$ & $(0.182)$ & $(0.160)$ & $(0.167)$ \\
\hline \multirow[t]{2}{*}{ Log distance to Xixi Wetland } & -0.134 & -0.129 & -0.125 & -0.120 \\
\hline & $(0.137)$ & $(0.133)$ & $(0.132)$ & $(0.141)$ \\
\hline \multirow[t]{2}{*}{ Log distance to Qiantang River } & 0.001 & 0.002 & -0.004 & 0.011 \\
\hline & $(0.069)$ & $(0.071)$ & $(0.082)$ & $(0.071)$ \\
\hline \multirow[t]{2}{*}{ Constant } & $16.398^{* * *}$ & $16.460^{* * *}$ & $16.562^{* * *}$ & $16.254^{* * *}$ \\
\hline & $(1.103)$ & $(1.139)$ & $(1.026)$ & $(0.908)$ \\
\hline Land transaction methods dummies & Yes & Yes & Yes & Yes \\
\hline Other controls & Yes & Yes & Yes & Yes \\
\hline Year fixed effects & Yes & Yes & Yes & Yes \\
\hline District fixed effects & Yes & Yes & Yes & Yes \\
\hline Observations & 390 & 390 & 390 & 390 \\
\hline$R^{2}$ & 0.708 & 0.712 & 0.715 & 0.726 \\
\hline
\end{tabular}

Notes: ${ }^{*} p<0.1,{ }^{* *} p<0.05,{ }^{* * *} p<0.01$. Standard errors clustered at prefecture city level are reported in parentheses. Other controls consist of land usage and land source dummy variables. 
within $10 \mathrm{~km}$. This suggests that the capitalization effects of the G20-related expressway on land prices are larger over $10 \mathrm{~km}$ away.

Table 10 provides the results of the effect of G20-related tunnel construction on land prices. Column 4 shows that land parcels near the G20-related tunnel increased in price after the G20 Summit. In comparison, land prices increased more at $10-40 \mathrm{~km}$ from the expressway than within $10 \mathrm{~km}$. These results are similar to those of the effect of the G20-related expressway on land prices.
Overall, the above micro parcel-level analysis of land prices within Hangzhou city shows that both G20 venue and transportation infrastructure construction raise land price after the G20 Summit.

\section{Conclusions}

Based on national land transaction data, our study provides empirical evidences for the effects of the 2016 G20 Summit on the land market. First, we find that the G20

Table 10. Effect of G20 related tunnel construction on land prices

\begin{tabular}{|c|c|c|c|c|}
\hline Variables & (1) & (2) & (3) & (4) \\
\hline \multirow{2}{*}{$\begin{array}{l}<10 \mathrm{~km} \text { distance to G20Tunnel } \\
\times \text { PostG20 }\end{array}$} & 0.005 & & & $0.547^{* * *}$ \\
\hline & $(0.161)$ & & & $(0.115)$ \\
\hline \multirow{2}{*}{$\begin{array}{l}\text { 10-20 km distance to G20Tunnel } \\
\times \text { PostG20 }\end{array}$} & & $0.556^{* *}$ & & $0.912^{* * *}$ \\
\hline & & $(0.186)$ & & $(0.220)$ \\
\hline \multirow{2}{*}{$\begin{array}{l}20-40 \mathrm{~km} \text { distance to G20Tunnel } \\
\times \text { PostG20 }\end{array}$} & & & $0.429^{* *}$ & $0.700^{* \star *}$ \\
\hline & & & $(0.154)$ & $(0.167)$ \\
\hline \multirow[t]{2}{*}{$<10 \mathrm{~km}$ distance to G20Tunnel } & -0.111 & & & -0.069 \\
\hline & $(0.165)$ & & & $(0.231)$ \\
\hline \multirow[t]{2}{*}{$10-20 \mathrm{~km}$ distance to G20Tunnel } & & -0.073 & & -0.036 \\
\hline & & $(0.084)$ & & $(0.098)$ \\
\hline \multirow[t]{2}{*}{ 20-40 km distance to G20Tunnel } & & & -0.001 & 0.042 \\
\hline & & & $(0.207)$ & $(0.107)$ \\
\hline \multirow[t]{2}{*}{ Log area } & -0.037 & -0.040 & -0.036 & -0.047 \\
\hline & $(0.050)$ & $(0.048)$ & $(0.058)$ & $(0.054)$ \\
\hline \multirow[t]{2}{*}{ Land location grade } & $-0.122^{* * *}$ & $-0.118^{* * *}$ & $-0.120^{* * *}$ & $-0.124^{* * *}$ \\
\hline & $(0.028)$ & $(0.022)$ & $(0.033)$ & $(0.032)$ \\
\hline \multirow[t]{2}{*}{ Year limit } & 0.010 & 0.013 & 0.012 & 0.014 \\
\hline & $(0.008)$ & $(0.008)$ & $(0.010)$ & $(0.009)$ \\
\hline \multirow[t]{2}{*}{ Floor area ratio } & $0.202^{* *}$ & $0.198^{* *}$ & $0.201^{* *}$ & $0.205^{* *}$ \\
\hline & $(0.070)$ & $(0.072)$ & $(0.073)$ & $(0.068)$ \\
\hline \multirow[t]{2}{*}{ Log distance to CBD } & $-0.379^{\star}$ & $-0.384^{*}$ & $-0.335^{*}$ & $-0.392^{*}$ \\
\hline & $(0.172)$ & $(0.172)$ & $(0.164)$ & $(0.188)$ \\
\hline \multirow[t]{2}{*}{ Log distance to closest subway station } & 0.076 & 0.063 & $0.062^{*}$ & 0.070 \\
\hline & $(0.050)$ & $(0.041)$ & $(0.032)$ & $(0.038)$ \\
\hline \multirow[t]{2}{*}{ Log distance to closest bus station } & $-0.152^{*}$ & $-0.150^{* *}$ & $-0.148^{* *}$ & $-0.160^{* *}$ \\
\hline & $(0.067)$ & $(0.058)$ & $(0.064)$ & $(0.061)$ \\
\hline \multirow[t]{2}{*}{ Log distance to West Lake } & -0.202 & -0.185 & -0.220 & -0.207 \\
\hline & $(0.184)$ & $(0.182)$ & $(0.164)$ & $(0.168)$ \\
\hline \multirow[t]{2}{*}{ Log distance to Xixi Wetland } & -0.107 & -0.135 & -0.133 & -0.099 \\
\hline & $(0.153)$ & $(0.122)$ & $(0.143)$ & $(0.156)$ \\
\hline \multirow[t]{2}{*}{ Log distance to Qiantang River } & -0.018 & -0.004 & -0.004 & -0.012 \\
\hline & $(0.072)$ & $(0.073)$ & $(0.079)$ & $(0.078)$ \\
\hline \multirow[t]{2}{*}{ Constant } & $16.606^{* * *}$ & $16.546^{* * *}$ & $16.372^{* * *}$ & $16.520^{* * *}$ \\
\hline & $(1.092)$ & $(1.070)$ & $(1.037)$ & $(0.967)$ \\
\hline Land transaction methods dummies & $16.606^{* * *}$ & $16.546^{* * *}$ & $16.372^{* * *}$ & $16.520^{* * *}$ \\
\hline Other controls & $(1.092)$ & $(1.070)$ & $(1.037)$ & $(0.967)$ \\
\hline Year fixed effects & Yes & Yes & Yes & Yes \\
\hline District fixed effects & Yes & Yes & Yes & Yes \\
\hline Observations & 390 & 390 & 390 & 390 \\
\hline$R^{2}$ & 0.709 & 0.717 & 0.711 & 0.727 \\
\hline
\end{tabular}

Notes: ${ }^{*} p<0.1,{ }^{* *} p<0.05,{ }^{* *} p<0.01$. Standard errors clustered at prefecture city level are reported in parentheses. Other controls consist of land usage and land source dummy variables. 
Summit significantly increases land prices in the host city by $22.6 \%$. The economic benefit of hosting the G20 Summit would be about 51.1 billion yuan (7.6 billion dollar) annually $(22.6 \% \times 226.2$ billion yuan of land sale revenue in the primary land market of Hangzhou in 2017), which is less than the amount of investment, 120 billion yuan. However, considering the capitalization effect of hosting G20 Summit on the real estate market and the increase of business environment, the benefit would be larger and probably more than the cost, which need further study. Second, we find spatial and temporal heterogeneous effects of the G20 Summit on the land market. The impact of the G20 Summit on the land market is larger in the post-G20 period than that in the preparation period. Third, we find evidence for sizable spatial heterogeneous effects of the G20 Summit on land prices. Fourth, we also investigate the mechanisms through which hosting the G20 Summit affects the land market and find that the capitalization effects of G20 venue construction and transportation infrastructure upgrading on land prices are the two significant channels.

Our study offer several policy implications. First, hosting the G20 Summit can have positive effects on the land market in the host city, implying a positive economic benefit. However, this capitalization effect may have unintended consequences. The increased land prices may raise the cost of living and production, and thus would harm the city's competitiveness. The governments should realize the land price effect of mega-event and regulate the land market for suppressing prices. The capitalization effect of public investment has a perverse effect in that it benefits property owners rather than the host city's newcomers and renters. The government should use property tax for value capture and subsidize the worse-off newcomers and renters. Further, given the large amount of capital, resources and investment provided to host the mega-event, issues of equity, distributional justice and efficiency should become an important concern for public policy. The government should well understand the heterogeneous effects of the mega-event's and implement the balance development policy for improving region's efficiency and equity under the mega-event.

Our study relates to the literature on cost-benefit analyses of mega-events. We explore the land market impacts of the G20 Summit, taking Hangzhou as a case. Whether our results can apply to other G20 Summit cities need further study. The effects of hosing G20 Summit may depend on city's size, industry structure, development stage and project investments. However, our analysis and methodology would enlighten further research on the capitalization effects of mega-events.

\section{Funding}

This research was supported by National Social Science Foundation of China (No. 17BGL130), National Natural Science Foundation of China (No. 72074079; No. 71774143), Project of Philosophy and Social Science of Zhejiang Province (20NDJC048YB), East China Normal University's Recruited Talents Research Starting Project of Fundamental Research Funds for the Central Universities (2020ECNU-HLYT033), National Natural Science Foundation of China (No. 71803179), and Major Project of Philosophy and Social Science of the Chinese Ministry of Education (18JZD033).

\section{Author contributions}

Xuejun Du and Zhonghua Huang conceived the study and were responsible for the design and development of the data analysis. Xuejun Du and Zhonghua Huang were responsible for data collection, analysis and interpretation. Xuejun Du and Zhonghua Huang wrote the first draft of the article.

\section{Disclosure statement}

The authors declare that they have no competing financial, professional, or personal interests from other parties.

\section{References}

Ahlfeldt, G. M., \& Kavetsos, G. (2014). Form or function?: the effect of new sports stadia on property prices in London. Journal of the Royal Statistical Society: Series A (Royal Statistical Society), 177(1), 169-190. https://doi.org/10.1111/rssa.12006

Ahlfeldt, G. M., \& Maennig, W. (2010). Impact of sports arenas on land values: evidence from Berlin. The Annals of Regional Science, 44(2), 205-227. https://doi.org/10.1007/s00168-008-0249-4

Ahlfeldt, G. M., Maennig, W., \& Richter, F. J. (2017). Urban renewal after the Berlin Wall: a place-based policy evaluation. Journal of Economic Geography, 17(1), 129-156. https://doi.org/10.1093/jeg/lbw003

Cai, H., Henderson, J. V., \& Zhang, Q. H. (2013). China's land market auctions: evidence of corruption? The RAND Journal of Economics, 44(3), 488-521. https://doi.org/10.1111/1756-2171.12028

Chen, Y. Y., Jin, G. Z., Kumar, N., \& Shi, G. (2013). The promise of Beijing: evaluating the impact of the 2008 Olympic Games on air quality. Journal of Environmental Economics and Management, 66, 424-443.

https://doi.org/10.1016/j.jeem.2013.06.005

Currie, J., Davis, L., Greenstone, M., \& Walker, R. (2015). Environmental health risks and housing values: evidence from 1,600 toxic plant openings and closings. American Economic Review, 105(2), 678-709. https://doi.org/10.1257/aer.20121656

Ding, C., \& Lichtenberg, E. (2011). Land and urban economic growth in China. Journal of Regional Science, 51(2), 299-317. https://doi.org/10.1111/j.1467-9787.2010.00686.x

Du, X. J., \& Huang, Z. H. (2017). Ecological and environmental effects of land use change in rapid urbanization: the case of Hangzhou, China. Ecological Indicators, 81, 243-251.

https://doi.org/10.1016/j.ecolind.2017.05.040

Du, X. J., \& Huang, Z. H. (2018). Spatial and temporal effects of urban wetlands on housing prices: evidence from Hangzhou, China. Land Use Policy, 73, 290-298.

https://doi.org/10.1016/j.landusepol.2018.02.011 
George, H. (1879). Progress and poverty. Robert Schalkenbach Foundation.

Hilber, C. A. L. (2017). The economic implications of house price capitalization: a synthesis. Real Estate Economics, 45(2), 301-339. https://doi.org/10.1111/1540-6229.12129

Ho, S. P. S., \& Lin, G. C. S. (2003). Emerging land markets in rural and urban China: policies and practices. The China Quarterly, 175, 681-707. https://doi.org/10.1017/S0305741003000407

Huang, Z. H., \& Du, X. J. (2015). Assessment and determinants of residential satisfaction with public housing in Hangzhou, China. Habitat International, 47, 218-230. https://doi.org/10.1016/j.habitatint.2015.01.025

Huang, Z. H., \& Du, X. J. (2017a). Government intervention and land misallocation: evidence from China. Cities, 60, 323-332. https://doi.org/10.1016/j.cities.2016.10.006

Huang, Z. H., \& Du, X. J. (2017b). Strategic interaction in local governments' industrial land supply: evidence from China. Urban Studies, 54(6), 1328-1346. https://doi.org/10.1177/0042098016664691

Huang, Z. H., \& Du, X. J. (2018). Holding the market under the stimulus plan: local government financing vehicle's land purchasing behavior in China. China Economic Review, 50, 85-100. https://doi.org/10.1016/j.chieco.2018.04.004

Huang, Z. H., \& Du, X. J. (2021). Does air pollution impact investor cognition and valuation? Evidence from the Chinese land market. Real Estate Economics, 1-21. https://doi.org/10.1111/1540-6229.12344

Kavetsos, G. (2012). The impact of the London Olympics announcement on property prices. Urban Studies, 49, 14531470. https://doi.org/10.1177/0042098011415436

Kontokosta, C. (2012). The price of victory: the impact of the Olympic games on residential real estate markets. Urban Studies, 49(5), 961-978. https://doi.org/10.1177/0042098011411952

Kuminoff, N. V., \& Pope J. C. (2014). Do "capitalization effects" for public goods reveal the public's willingness to pay? International Economic Review, 55(4), 1227-1250.

https://doi.org/10.1111/iere.12088

Kuminoff, N. V., \& Pope, J. C. (2012). The value of residential land and improvements during the great housing boom and bust. Land Economics, 89(1), 1-29. https://doi.org/10.3368/le.89.1.1

Lin, G. C. S., \& Ho, S. P. S. (2005). The state, land system, and land development processes in contemporary China. Annals of the Association of American Geographers, 95(2), 411-436. https://doi.org/10.1111/j.1467-8306.2005.00467.x

Marris, T. (1987). The role and impact of mega-events and attractions on regional and national tourism development resolutions. Tourism Review, 42, 3-12. https://doi.org/10.1108/eb057975
Rappaport, J. (2009). The increasing importance of quality of life. Journal of Economic Geography, 9(6), 779-804. https://doi.org/10.1093/jeg/lbp009

Tao, R., Su, F. B., Liu, M. X., \& Cao, G. Z. (2010). Land leasing and local public finance in China's regional development: evidence from prefecture-level cities. Urban Studies, 47(10), 2217-2236. https://doi.org/10.1177/0042098009357961

Touseef, H., Jaffar, A., Zou, W., Shakeel, A., Bi, X. H., \& Zhu, G. L. (2021). Impact of urban village disamenity on neighboring residential properties: empirical evidence from Nanjing through hedonic pricing model appraisal. Journal of Urban Planning and Development, 147(1), 1-13. https://doi.org/10.1061/(ASCE)UP.1943-5444.0000645

Tu, C. (2005). How does a new sports stadium affect housing values? The case of FedEx Field. Land Economics, 81, 379-395. https://doi.org/10.3368/le.81.3.379

Tyrrell, M. (1987). The role and impact of mega-events and attractions on regional and national tourism development resolutions. The Tourist Review, 42(4), 3-12. https://doi.org/10.1108/eb057975

Wang, H., Wang, L. L., Su, F. B., \& Tao, R. (2012). Rural residential land use in China: patterns, efficiency and prospects for reform. Habitat International, 36(2), 201-209. https://doi.org/10.1016/j.habitatint.2011.06.004

Wang, M., \& Bao, H. X. H. (2018). Mega-event effects on the housing market: evidence from the Beijing 2008 Olympic Games. Cities, 72, 207-2016. https://doi.org/10.1016/j.cities.2017.07.014

Wang, M., Bao, H. X. H., \& Lin, P. (2015). Behavioural insights into housing relocation decisions: the effects of the Beijing Olympics. Habitat International, 47, 20-28. https://doi.org/10.1016/j.habitatint.2015.01.001

Witt, S. F. (1988). Mega-events and mega-attractions. Tourism Management, 9(1), 76-77. https://doi.org/10.1016/0261-5177(88)90063-5

Zhao, X. B., Ching, L., He, Y., \& Chan, N. Y. M. (2017). Playing games and concepts: Beijing Olympics and China urban development model. Journal of Contemporary China, 26, 465487. https://doi.org/10.1080/10670564.2016.1245896

Zhu, H. J., Deng, Y. H., Zhu, R., \& He, X. B. (2016). Fear of nuclear power? Evidence from Fukushima nuclear accident and land markets in China. Regional Science and Urban Economics, 60, 139-154. https://doi.org/10.1016/j.regsciurbeco.2016.06.008

Zhu, J. (2005). Transitional institutions for the emerging land market in China. Urban Studies, 42(8), 1369-1390. https://doi.org/10.1080/00420980500150714 